Volume and Issues Obtainable at Center for Sustainability Research and Consultancy
Journal of Accounting and Finance in Emerging Economies
ISSN: 2518-0318 ISSN (E) 2518-8488
Volume 6: Issue 2 June 2020
CSRE
Journal homepage: www.publishing.globalcsrc.org/jafee

\title{
Job Satisfaction among University Teachers working in Private Sector in the Punjab Province of Pakistan: A Quantitative Investigation
}

\author{
${ }^{1}$ Sumaira Munawar, ${ }^{2}$ Rukhsana Bashir, ${ }^{3}$ Misbah Malik \\ ${ }^{1}$ Assistant Professor, Department of Education, Lahore Leads University, Lahore-Pakistan, \\ sumairamunawar16@gmail.com \\ ${ }^{2}$ Assistant Professor, Department of Special Education, University of the Punjab, Lahore-Pakistan, \\ rukhsana.dse@pu.edu.pk \\ ${ }^{3}$ Assistant Professor, Institute of Education and Research, University of the Punjab, Lahore-Pakistan, \\ misbah.ier@pu.edu.pk
}

\begin{abstract}
ARTICLE DETAILS
History

Revised format: May 2020

Available Online: June 2020

\section{Keywords}

Teaching practice, prospective teachers, higher education, attitude
\end{abstract}

JEL Classification

$M 1, M 2$

\begin{abstract}
Job satisfaction is a feeling of pride and worker success on the job. It is generally perceived to be directly related to both profitability and personal wellbeing. This study aimed to discover teachers' perceptions about their job satisfaction based on the demographic characteristics of gender at private sector universities in Lahore district, Pakistan. The population of study consisted of all faculty members of all the private universities situated in district Lahore. Sample comprised 300 Lecturers, Assistant Professors, and Associate Professors selected through proportionate stratified random sampling technique. Proportion of male and female teachers was 179 and 129 respectively. A Likert type instrument was developed having 28 statements which were related to the factors of job satisfaction opportunity, organization, safety security, pay, working condition, policies practices, relationship with coworkers, relationship with supervisors, working environment, stress and work load. Reliability of the instrument was 0.781 which showed that the questionnaire was accurate. Findings of the study showed that male and female teachers had perceived equally towards all factors of job satisfaction, whereas no significant difference was found regarding opportunity, organization, pay, working condition, policies and practices, and relationship with coworkers between male and female teachers. It is recommended that universities, administrators, educational consultants, deans of universities should use strategic action for producing and sustaining job satisfaction among university teachers.
\end{abstract}

\section{OPEN ACCESS}

(C) 2020 The authors, under a Creative Commons AttributionNonCommercial 4.0

Corresponding author's email address: sumairamunawar16@gmail.com

Recommended citation: Munawar, S., Bashir, R., and Malik, M. (2020). Job Satisfaction among University Teachers working in Private Sector in the Punjab Province of Pakistan: A Quantitative Investigation. Journal of Accounting and Finance in Emerging Economies, 6(2), 615-621 


\section{Introduction}

A lot of attention has been received from many scholars about job satisfaction in the past decades. For example, Pan, Shen, Liu, Yang, \& Wang, (2015) described that recently among faculties of higher education studies on job satisfaction and working conditions is becoming essential issue. The level of workers' job satisfaction all stakeholders and government institutions hire employees for their organization. In order to know the job satisfaction level, way to motivate employees and other workers is also need to know for an employer. Toker (2011) stated if a worker will perform his duty with hard work if he is satisfied with his job.

A well-established facet in the glob is that a disappointed worker will have negative attitude if he is not satisfied with his job as compared to the satisfied worker. Job satisfaction "can be seen as a global feeling about the job, or as a related collection of attitudes regarding various aspects or facets of the job" (Kovach, 1977; Spector, 1997 and Saner \& Eyupoglu, 2012). A person who holds a series of positive and negative feelings towards their work is called satisfaction. A delight part of life is job satisfaction. A task associated with enjoyment and contentment is called satisfaction, whereas an emotional respond towards a task is called emotions. According to Seifert \& Unbeach, (2008) in organizational psychology job satisfaction is the widely studies topic in the world. Resulting from one's job and experience a positive and pleasure state of mind is characterized as job satisfaction. Job satisfaction in the form of individuals and workplace environment always give positive results in any organization. According to Machado, Soares, Brites, Ferreira, Farhangmehr, Gouveia, \& Peterson (2016). Lease (1998) a satisfied worker always seems to be active, present, always show commitment to their work, satisfied with their living standards and more productive. Level of employees' job satisfaction is influenced by many factors. The prime factors are working condition of an organization, interpersonal relationships, job itself, leadership and proper promotion criteria in an organization. Many tasks are done by employees in this regard, for example, employee should take interest in job and encountered challenges at job place, various tasks and consistency in job are included. Individuals who are happy inside are able to call a satisfied worker. The human relation approach becomes popular in order to increase the importance of job satisfaction. Many behavioural factors like patterns, perception and situations are involved in job satisfaction (Saner \& Eyupoglu, 2012).

The studies like ( Cano \& Castillo, 2004; Al-Smadi \& Qalan, 2015; Bozeman \& Gaughan, 2011; Filiz, 2014 and Ping, Lai \& Lo, 2010) were conducted on job satisfaction of university teachers. Level of academic staff job satisfaction was investigated under these studies. In general the significance and employees' level of job satisfaction is investigated in these studies and suggested to do more studies in this area. The impact of level of job satisfaction in terms of demographic variables was investigated like gender, age, experience, qualification etc. in many studies. Whenever and wherever the studies on job satisfaction with different perspectives were conducted have same and sometimes different results in all over the world. for example a study conducted by Liu et al. (2015) concluded that female are less satisfied than male employees.

The following study is guided by Herzberg two factor theory in 1959 which is also called motivation-hygiene theory. The hygiene factors for example, status, job security, relationships with employer, organizational policies, and working conditions are usually try to acquire by employees. Satisfaction itself is considered the temporary factor which fades hygiene influence on individuals' level of job satisfaction. Therefore, the hygiene needs are sometimes did not make employees motivate, where employers and managers need to understand. Employees' achievements, development and progression are motivation factors which lead an employee towards job satisfaction but the real motivation factors are work itself, job responsibility and recognition. The following study intends to investigate job satisfaction of university teachers on the basis of their gender at Punjab, Province Pakistan.

\subsection{Objectives of the Study}

To compare the perceptions of male and female lecturers, assistant professors, associate professors and professors about job satisfaction of private universities.

\section{Methodology}

This study was quantitative and descriptive in nature. for examining the study, the following procedures were adopted. 


\subsection{Population}

The population of the study consists of all the faculty members of all the private universities situated in district Lahore. Registrars of all the 17 universities situated in Lahore district were requested to provide information regarding faculty of their respective university. In total three universities namely, Lahore university of Management sciences, Lahore, Riphah international university

\begin{tabular}{lcccc}
\hline Name of university & Professes & Lecturer & Associate Professors & $\begin{array}{c}\text { Assistant } \\
\text { Professors }\end{array}$ \\
\hline Lahore university of Management sciences, Lahore. & & 92 & 192 & 99 \\
Riphah international university, Lahore. & 62 & 120 & 134 & 120 \\
Qarshi university, Lahore. & 4 & 40 & 120 & 60 \\
Total & 52 & 252 & 446 & 270 \\
\hline
\end{tabular}

\subsection{Sample}

Proportional Stratified random sampling used for selecting the sample of 300 lecturers, assistant professors, associate professors and professors of private universities of Lahore. The sample was selected randomly from each stratum on the basis of private university teachers and designation by choosing $30 \%$ of population to make the sample more representative.

\subsection{Instrument}

The instrument was carefully developed for determining the perception of university teachers about job satisfaction by using Five-point Likert's Scale. Twenty-eight statements were related the factors of job satisfaction opportunity, organization, safety security, pay, working condition, policies practices, relationship with coworkers, relationship with supervisors, working environment, stress and work load. Before collecting the data, the questionnaire was validated through pilot testing from 4 University teachers in order to check the reliability. Reliability of 28 items was 0.781 which showed that the questionnaire was accurate.

\section{Data Analysis}

\section{Table 1}

"Mean Difference in Male and Female Teachers' Perception about opportunity for factor of job satisfaction in private universities of Lahore"

\begin{tabular}{llcccccc}
\hline & Gender & $\mathrm{N}$ & $\mathrm{M}$ & $\mathrm{SD}$ & $\mathrm{Df}$ & $\mathrm{t}$-value & Sig. \\
\hline \multirow{2}{*}{ Opportunity } & Male & 171 & 18.86 & 2.076 & 298 & .713 & .447 \\
& Female & 129 & 18.65 & 2.989 & & & \\
\hline
\end{tabular}

The t-value $=.713, p=.477$, is not significant at level of significance for perceived opportunity factor of job satisfaction on the basis of gender' perceptions. The mean score of males' (171) and females' respondents, was (129) respectively. It is concluded that both male and female private university faculty had same perception about opportunity factor of job satisfaction.

\section{Table 2}

"Mean Difference in Male and Female Teachers' Perception about organization for factor of job satisfaction in private universities of Lahore"

\begin{tabular}{llllllll} 
& Gender & $\mathrm{N}$ & $\mathrm{M}$ & $\mathrm{SD}$ & $\mathrm{df}$ & $\mathrm{t}$-value & Sig. \\
\hline Organization & Male & 171 & 6.78 & 1.450 & 298 & 1.713 & .088 \\
& Female & 129 & 7.08 & 1.564 & & & \\
\hline
\end{tabular}

The t-value $=1.713, p=.088$, is not significant at level of significance for perceived Organization factor of job satisfaction on the basis of male and female perceptions. The mean score of males' (171) and females' respondents, 
was (129) respectively. It is concluded that both male and female private university faculty had same perception about Organization factor of job satisfaction.

\section{Table 3}

"Mean Difference in Male and Female Teachers' Perception about Safety Security for job satisfaction in private universities of Lahore"

\begin{tabular}{llcccccc}
\hline & Gender & $\mathrm{N}$ & $\mathrm{M}$ & $\mathrm{SD}$ & $\mathrm{df}$ & $\mathrm{t}$-value & Sig. \\
\hline \multirow{2}{*}{ Safety Security } & Male & 171 & 9.91 & 1.545 & 298 & .3 .138 & .002 \\
& Female & 129 & 10.64 & 2.474 & & & \\
\hline
\end{tabular}

The t-value $=3.138, p=.002$, is significant at level of significance for perceived safety and security factor of job satisfaction on the basis of male and female perceptions. The mean score of males' (171) and females' respondents, was (129) respectively. It is concluded that both male and female private university faculty had same perception about safety and security factor of job satisfaction

\section{Table 4}

"Mean Difference in Male and Female Teachers' Perspective about the Relationship to the Environment is Considered Important in DHA School System Lahore"

\begin{tabular}{llcccccc} 
& Gender & $\mathrm{N}$ & $\mathrm{M}$ & SD. & df & t-value & Sig. \\
\hline \multirow{2}{*}{ Pay } & Male & 171 & 6.72 & 1.929 & 298 & 1.585 & .114 \\
& Female & 129 & 6.36 & 1.908 & & & \\
\hline
\end{tabular}

The t-value $=1.585, p=.114$, is not significant at level of significance for perceived Pay factor of job satisfaction on the basis of male and female perceptions. The mean score of 'males (171) and females' respondents, was (129) respectively. It is concluded that both male and female private university faculty had same perception about pay factor of job satisfaction.

\section{Table 5}

"Mean Difference in Male and Female Teachers' Perception about working condition for job satisfaction in private universities of Lahore"

\begin{tabular}{llllllll} 
& Gender & $\mathrm{N}$ & $\mathrm{M}$ & SD. & df & t- & Sig. \\
\hline Working Conditions & Male & 171 & 20.38 & 1.645 & 298 & .085 & .938 \\
& Female & 129 & 20.81 & 1.681 & & & \\
\hline
\end{tabular}

The t-value $=.085, p=.932$, is not significant at level of significance for perceived working condition factor of job satisfaction on the basis of male and female perceptions. The mean score of males' (171) and females' respondents, was (129) respectively. It is concluded that both male and female participants had perceived equally towards working condition factor of job satisfaction. 


\section{Table 6}

"Mean Difference in Male and Female Teachers' Perception about policies practices for job satisfaction in private universities of Lahore"

\begin{tabular}{llllllll}
\hline & Gender & $\mathrm{N}$ & $\mathrm{M}$ & SD. & Df & t-value & Sig. \\
\hline Policies Practices & Male & 171 & 6.84 & 1.743 & 298 & 1.429 & .154 \\
& Female & 129 & 6.54 & 1.867 & & &
\end{tabular}

The t-value $=1.429, p=.154$, is not significant at level of significance for perceived policies and practices factor of job satisfaction on the basis of male and female perceptions. The mean score of males' (171) and females' respondents, was (129) respectively. It is concluded that both male and female private university faculty had same perception about policies and practices factor of job satisfaction.

\section{Table 7}

"Mean Difference in Male and Female Teachers' Perception about relationship with coworkers for job satisfaction in private universities of Lahore"

\begin{tabular}{llcccccc} 
& Gender & $\mathrm{N}$ & $\mathrm{M}$ & SD. & Df & t-value & Sig. \\
\hline Relationship with Coworkers & Male & 171 & 6.71 & 1.335 & 298 & 1.057 & .291 \\
& Female & 129 & 6.87 & 1.141 & & & \\
\hline
\end{tabular}

The t-value $=1.057, p=.291$, is not significant at level of significance for perceived Relationship with coworker factor of job satisfaction on the basis of male and female perceptions. The mean score of males' (171) and females' respondents, was (129) respectively. It is concluded that both male and female private university faculty had same perception about Relationship with coworker factor of job satisfaction.

\section{Table 8}

"Mean Difference in Male and Female Teachers' Perception about relationship with supervisors for job satisfaction in private universities of Lahore"

\begin{tabular}{llllllll} 
& Gender & $\mathrm{N}$ & $\mathrm{M}$ & SD. & Df & t-value & Sig. \\
\hline \multirow{2}{*}{ Relationship with Supervisors } & Male & 171 & 5.46 & 1.386 & 298 & 1.646 & .101 \\
& Female & 129 & 5.74 & 1.641 & & & \\
\hline
\end{tabular}

The $\mathrm{t}$-value $=1.646, p=.101$, is not significant at level of significance for perceived relationship with coworker factor of job satisfaction on the basis of male and female perceptions. The mean score of males' (171) and females' respondents, was (129) respectively. It is concluded that both male and female private university faculty had same perception about relationship with coworker factor of job satisfaction.

\section{Table 9}

"Mean Difference in Male and Female Teachers' Perception about working environment for job satisfaction in private universities of Lahore"

\begin{tabular}{llcccccc}
\hline & Gender & $\mathrm{N}$ & $\mathrm{M}$ & $\mathrm{SD}$ & $\mathrm{df}$ & $\mathrm{t}$-value & Sig. \\
\hline \multirow{2}{*}{ Working Environment } & Male & 171 & 9.85 & 2.292 & 298 & 2.281 & .023 \\
& Female & 129 & 10.47 & 2.305 & & & \\
\hline
\end{tabular}


The t-value $=2.281, p=.023$, is significant at level of significance for perceived working environment factor of job satisfaction on the basis of male and female perceptions. The mean score of males' (171) and females' respondents, was (129) respectively. It is concluded that both male and female private university faculty had same perception about working environment factor of job satisfaction.

\section{Table 10}

"Mean Difference in Male and Female Teachers' Perception about stress for job satisfaction in private universities of Lahore"

\begin{tabular}{llllllll}
\hline & Gender & $\mathrm{N}$ & $\mathrm{M}$ & $\mathrm{SD}$ & $\mathrm{Df}$ & $\mathrm{t}$-value & Sig. \\
\hline \multirow{2}{*}{ Stress } & Male & 171 & 6.72 & 1.312 & 298 & 4.400 & .000 \\
& Female & 129 & 7.43 & 1.494 & & & \\
\hline
\end{tabular}

The t-value $=4.400, p=.000$, is significant at level of significance for perceived stress factor of job satisfaction on the basis of male and female perceptions. The mean score of males' (171) and females' respondents, was (129) respectively. It is concluded that both male and female private university faculty had same perception about stress factor of job satisfaction.

\section{Table 11}

"Mean Difference in Male and Female Teachers' Perception about work load for job satisfaction in private universities of Lahore"

\begin{tabular}{llllllll} 
& Gender & $\mathrm{N}$ & $\mathrm{M}$ & $\mathrm{SD}$ & $\mathrm{Df}$ & $\mathrm{t}$-value & Sig. \\
\hline \multirow{2}{*}{ Work Load } & Male & 171 & 5.78 & 1.869 & 298 & 3.055 & .002 \\
& Female & 129 & 6.44 & 1.858 & & & \\
\hline
\end{tabular}

The t-value $=3.055, p=.002$, is significant at level of significance for perceived workload factor of job satisfaction on the basis of male and female perceptions. The mean score of males' (171) and females' respondents, was (129) respectively. It is concluded that both male and female private university faculty had same perception about workload factor of job satisfaction.

\section{Conclusions}

It is concluded that both male and female participants had perceived equally towards all factors of job satisfaction. The study results indicated that there are statistically significant differences in the level of job satisfaction of private Universities faculty towards safety and security, working environment, stress and workload this showed the level of job satisfaction was in favour of males because they were provided a safe and secure working environment, male members were comfortable with the work, but female faculty have to look after the children with their jobs. The results of this study were similar with the studies of Agarwal and Mehta, (2014), Syed, (2013), Ahmad and Shahzad, (2011) \& Aziri (2011) described that job satisfaction directly effect on the performance of University teachers. Therefore, it is recommended universities, administrators, educational consultants deans of universities used strategic action for producing and sustaining the job satisfaction among university teachers. They should develop supportive culture and facilitates the faculty with research funds, launch professional training programmes for their job satisfaction and motivate them for decision making.

\section{References}

Ahmad, S., \& Shahzad, K. (2011). HRM and employee performance: A case of university teachers of Azad Jammu and Kashmir (AJK) in Pakistan. African Journal of Business Management, 5(13), 5249.

Agarwal, R. N., \& Mehta, A. (2014). Impact of Performance Appraisal and Working Environment on the Job Satisfaction and Attrition Problem in the Indian IT Industry. Paradigm, 18(1), 73-85.

Al-Smadi, M. S., \& Qblan, Y. M. (2015). Assessment of Job Satisfaction among Faculty Members and Its Relationship with Some Variables in Najran University. Journal of Education and Practice, 6(35), 117-123. 2. 
Aziri, B. (2011). Job satisfaction: A literature review. Management Research and Practice, 3(4), 77-86.

Bozeman, B., \& Gaughan, M. (2011). Job satisfaction among university faculty: Individual, work, and institutional determinants. The Journal of Higher Education, 82(2), 154-186.

Filiz, Z. (2014). An analysis of the levels of job satisfaction and life satisfaction of the academic staff. Social Indicators Research, 116(3), 793-808.

Kovach, K.A. (1977). Organizational size, job satisfaction, absenteeism, and turnover. Washington, D.C. University Press of America.

Machado-Taylor, M.L., Soares, V.M., Brites, R., Ferreira, J.B., Farhangmehr, M., Gouveia, O., \& Peterson, M. (2016). Academic job satisfaction and motivation: findings from a nationwide study in Portuguese higher education. Studies in Higher Education, 41(3), 541-559.

Pan, B., Shen, X., Liu, L., Yang, Y., \& Wang, L. (2015). Factors Associated with Job Satisfaction among University Teachers in North-eastern Region of China: A Cross- Sectional Study. International journal of environmental research and public health,12(10), 12761-12775.

Saner, T., \& Eyupoglu, S.Z. (2012). The Age and Job Satisfaction Relationship in Higher Education. ProcediaSocial and Behavioral Sciences, 55(7), 1020-1026.

Saner, T., \& Eyupoglu, S.Z. (2013). The Gender-marital Status Job Satisfaction Relationship of Academics. ProcediaSocial and Behavioral Sciences, 106(80), 2817-2821.

Seifert, T.A., \& Umbach, P.D. (2008). The Effects of Faculty Demographic Characteristics and Disciplinary Context on Dimensions of Job Satisfaction. Research in Higher Education, 49(5), 357-381.

Spector, P.E. (1997). Job Satisfaction: Application, assessment, causes and consequences, Thousand Oaks, CA. Sage.

Syed, S. R. S. (2013). Job satisfaction in university employees: A case study of the university of kashmir (Doctoral dissertation). University of Kashmir.

Toker, B. (2011). Job satisfaction of academic staff: an empirical study on Turkey. Quality Assurance in Education, 19(2), 156-169. 